\title{
IMPACT OF ADDING MORINGA OLEIFERA ON THE QUALITY AND PROPERTIES OF HALLOUMI CHEESE
}

\author{
ELGAML, N.B; M.A.M. MOUSSA and A.E. SALEH
}

Dairy Res. Dept., Animal Pro. Res. Institute, Agric. Res. Center, Ministry of Agric, Egypt.

elgamlnabeel@yahoo.com

(Manuscript received 20 September 2017)

\begin{abstract}
$\mathrm{T}$

he aim of this study is to study the effect of adding moringa on the quality and properties of Halloumi cheese made from cow milk without moringa as a control (T1), added $3 \%$ moringa oleifera leaves powder extraction (MOLPE) in milk (T2) and added 3\% moringa oleifera leaves powder (MOLP) in weight curd cheese before pressed (T3). The second treatment had a higher yield \% due to the addition of MOLPE. However, the milk required / $\mathrm{kg}$ Halloumi cheese was less in yield than other treatments. Treatment (T2) had a higher in total solids (TS), fat, protein, water soluble nitrogen (WSN), salt, salt in moisture, ash, antioxidant, Iron content, gumminess and chewiness, than other treatment. Iron content of T2 increased from $0.85-9.02 \mathrm{mg} / 100 \mathrm{~g}$. From $10-15 \mathrm{mg}$ Iron is required on daily basis to growing children and nursing women thus eating $175 \mathrm{~g}$ of Halloumi cheese $\mathrm{T} 2$ can provide $15.79 \mathrm{mg}$ iron on daily basis $100 \%$ requirement of nursing women and children of iron. Fortification cheese with dry leaves powder and extract of Moringa oleifera can be resolve the problem of iron deficiency in women aged 15-50 and children in primary school of the world's population suffer from anemia. Evaluation of total bacteria counts in fresh Halloumi cheese samples were decreased 3.37, 2.03, and 1.88 ( $\log \mathrm{cfu} / \mathrm{g}$ ) for cheese made from $\mathrm{T} 1, \mathrm{~T} 2$, and $\mathrm{T} 3$, respectively. This might due to the high phenolic and antimicrobial compound content of Moringa. The total sensory evaluation in all treatments was not significantly affected by each other.
\end{abstract}

Keywords: Halloumi cheese, cow milk, moringa oleifera, antimicrobial, Iron, quality and properties, anemia.

\section{INTRODUCTION}

Traditionally ovine and caprine milk, or a mixture of both in various ratios, were used for the manufacture of Halloumi cheese, but nowadays the large dairies use bovine milk almost exclusively. This recent transition towards bovine milk has resulted from the low levels of production of ovine and caprine milk, but it has had an impact on the sensory quality of the cheese. A similar product under the same name in Syria and Lebanon, cheese is made as semi hard to hard cheese made mainly from sheep milk, although goat milk, cow milk or mixture of them in various ratios. The 
manufacture of Halloumi cheese has been described by Anifantakis and Kaminarides (1982). This fresh product has a characteristic aroma, its texture is elastic and compact with no holes and it is easily sliced. It is popular with consumers and large quantities of Halloumi are sold immediately after production. Halloumicheese made from cow's milk is more yellowish in colour and lacks the sensory characteristics of the Halloumi cheese that made from sheep's milk (Kaminarides et al., 2000).

The yeasts isolated from the commercial samples of fresh and mature Halloumi cheeses did not have any adverse effects on the flavour or produce visible defects. A new lactobacillus strain has been isolated from mature Halloumi cheese made in Cyprus, which suggests that this organism is resistant to high salt concentrations and low pH (Lawson et al., 2001). The moringa traditionally used for anemia, anxiety asthma, blackheads, bronchitis, catarrh, cholera, conjunctivitis, cough diarrhea, eye and ear infections, fever, swollen glands, headache. In the previous study, moringa leaves extract demonstrated anti-anemia activity in rats induced aniline (Fahey, 2005).

Approximately 162 billion people (24.8\%) from the world's population suffer from anemia and $50 \%$ of an anemic case is due to iron deficiency. Prevalence of anemia is about $21.7 \%$, and the prevalence of iron deficiency young women is about $28 \%$. Iron deficiency anemia can cause both growth disruption and disruption of physical and mental development, lower intellectual (McLean et al., 2009).

The addition of malunggay leaf powder (MLP) in cream cheese produced from buffalo's milk was investigated to compare the nutritive value, sensory quality and consumer acceptability and determine the optimum level of MLP. Moisture, fat, protein and calorie content of the cream cheese did not differ significantly among treatments while crude fiber content increased significantly with the addition of MLP. The inclusion levels of MLP had significant negative quadratic relationship with the colour and general acceptability of the cheese, texture, aroma, flavor and aftertaste had significant negative linear relations with the levels of MLP. Inclusion rate for malunggay powder lower than $0.5 \%$ should be considered in the production of cream cheese (Apilado et al., 2013). The moringa leaves extract could improve iron deficiency anemia. Chemical constituents of moringa leaves have been reported to have antihypertensive effects, anticancer, and antibacterial activity, namely4 (4'-O-acetyl-a-L-rhamnopyranosyloxy) benzylisothiocyanate, 4-(aLrhamnopyranosyloxy) benzylisothiocyanate), niazimicin A and B pterygospermin, benzyl isothiocyanate, and 4-(a-L-rhamnopyranosyloxy), niazimicin $A$ and $B$ pterygospermin, benzyl isothiocyanate, and 4-(a-L-rhamnopyranosyloxy) benzyl glucosinola (Suzana et al., 2017). 
The objective of the present work was to study effect of adding moringa oleifera on the yield, composition and quality of Halloumi cheese made from cow' milk since cow' milk is produced in huge quantity in Egypt.

\section{MATERIALS AND METHODS}

Milk:

Whole fresh cow's milk (3.8\% fat, $2.8 \%$ protein, $4.20 \%$ lactose, $0.7 \%$ ash and $88.5 \%$ moisture) was obtained from herds of Sakha Animal Production Research Station, Animal Production Research Institute, Agricultural Research Center, Ministry of Agricultural, Egypt.

\section{Moringa:}

Moringa oleifera leaves powder was obtained from National Research Center, Egypt. It contains $4.21 \%$ fat, $38.4 \%$ protein, $6.5 \%$ ash, $31.73 \%$ carbohydrate, $7.21 \%$ fiber and $11.5 \%$ moisture.

\section{Preparation of leaves extract from Moringa oleifera:}

Twenty grams of leaf powder Moringa oleifera was soaked in $200 \mathrm{ml}$ of boiling water for 60 minutes. The extract was filtrated using Whatman Paper no.1 and stored in the refrigerator pending use.

\section{Rennet:}

Standard powder microbial rennet (RENIPLUS 150G- Spain) was used as coagulant.

\section{Cheese making:}

Halloumi cheese was made from forty $\mathrm{kg}$ fresh cow milk. Cow milk without Moringa was served as a control. The treatments were carried out by adding $1 \%$ moringa oleifera leaves powder in milk (1\%MOLP), adding 3\% moringa oleifera leaves powder in curd (3\%MOLP), adding $6 \%$ moringa oleifera leaves powder in curd (6\% MOLP), adding 3\% moringa oleifera leaves powder extraction in milk (3\%MOLPE), and adding $6 \%$ moringa oleifera leaves powder extraction in milk (6\%MOLPE). Coagulation of milk by rennet at $35^{\circ} \mathrm{C}$ for $45 \mathrm{~min}$ after that the curd was cut into cubes $1 \mathrm{~cm}^{2}$ then coagulum was precipitated for $10 \mathrm{~min}$. The curd was pressed at 550 pa for $1 \mathrm{~h}$, after that was cut into blocks $(10 \times 10 \times 30 \mathrm{~cm})$ and the blocks in hot whey at $90^{\circ} \mathrm{C}$ for $1 \mathrm{~h}$, then drained, cooled and dry salt was added at $3 \% \mathrm{w} / \mathrm{w}$ were kept and sprinkled with dry peppermint leaves, in finally the cheese was stored in brine solution (12\% NaCl) as described by Anifantakis and Kaminarides (1982). 


\section{Preliminary sensory evaluation for fresh Halloumi cheese:}

The resultant Halloumi cheese with different concentrations (0\%MOLP, 1\% MOLP in milk, $3 \%$ MOLP in curd, $6 \%$ MOLP in curd, $1 \%$ MOLP in milk 3\% MOLPE in milk, and $6 \%$ MOLPE in milk) of moringa oleifera leaves powder (MOLP) or moringa oleifera leaves powder extraction (MOLPE) was evaluated by a panel of staff members at dairy laboratory in Sakha Animal Production Research. To choose the best concentrations.

Experimental planning and sampling: The resultant Halloumi cheese samples were analysed physico-chemically microbiologically, rheological and organoleptic properties.

\section{Cheese yield:}

Cheese yield $=\mathrm{kg}$ of cheese $/ \mathrm{kg}$ of milk $\times 100$.

\section{Physicochemical analyses:}

\section{Milk and cheese samples:}

The milk used for cheese making was weighed, and analyzed for fat, protein, lactose, and total solids (TS) by milko scan, model 133B. Also, analyzed Halloumi cheese samples as follows: total solid, total protein, water soluble nitrogen (WSN), ash, and fat were determined according to standard methods of A.O.A.C. (1990). Determined the minerals, ash was incinerated in a muffle furnace at $550{ }^{\circ} \mathrm{C}$ for 6hours. The solid contents $(15 \mathrm{~g})$ each of Halloumi cheese samples were digested in two volume of concatenated nitric acid then heated with one volume perchloric acid to dryness and cooled to room temperature $\left(24^{\circ} \mathrm{C}\right)$ as described by A.O.A.C. (1990). The cooled samples were diluted with deionised water and filtered after $6 \mathrm{~h}$. An Atomic Absorption Spectrophotometer (210VGP,Buck Scientific Manufactures) was used to determine the concentration of $\mathrm{Mg}, \mathrm{Na}, \mathrm{Ca}, \mathrm{P}$, and $\mathrm{Fe}$ of the samples.

\section{Textural profile analysis :}

Textural profile of Halloumi cheese was measured at $23^{\circ} \mathrm{C}$ as described by Kosikowski (1982). Using an Instron Universal Tasting Machin model 1195, StableMicro system. (SMS) LTD., Godalming, UK, loaded with Dimension software SMS program. Likwise, Penetration.

\section{Microbiological Estimation:}

Total plate counts of bacteria, coliform, E. coli, Staph. aureus, and molds\& yeasts were determined according to the method described by Houghtby et al (1992).

\section{Antioxidant activity by DPPH radical (\%):}

Test Methods it could be used Standard / Official methods (ISO), Su\& Silva (2010) .It was analysis in Food Technology Res. Institute.Agricultural Res. Center, Egypt. According to Lee et al. (2003).Radical scavenging activity was expressed as inhibition percentage and calculated using the followed formula: DPPH radical $\%=(1-$ 
sample absorbance/ control absorbance) $\times 100$. Analyses of all samples were run in triplicate and average.

\section{Sensory Evaluation:}

The organoleptic properties of the resultant Halloumi cheese were assessed by a test panel of 10 persons in Sakha Animal Production Research Station, Animal Production Research Institute according to the scheme described by Nelson and Trout (1981).

\section{Statistical Analysis :}

Results were statistically analyzed by one way complete design to study the effect of treatment using SAS (2004). However, the significant differences among means were tested using Duncan's Multiple Range Test Duncan (1955).

\section{RESULTS AND DISCUSSION}

Table (1) showed the organoleptic properties of Halloumi cheese made from cow milk by adding different ratio of moringa oleifera leaves powder (MOLP) or moringa oleifera leaves powder extract (MOLPE) .control had a highest score in the total sensory evaluation than the other treatments followed by two different treatments 3\% MOLP and 3\% MOLPE. Finally, added 1\% MOLP in milk, 6\% MOLP in curd yield, $1 \%$ MOLPE, and 6\% MOLPE. Results indicated that the use of concentration to $1 \%$ and $6 \%$ moringa oleifera resulted in rejected Halloumi cheese from technological and sensory evaluation point of review.

Sensory evaluation for Halloumi cheese was showed that the Halloumi cheese manufactured by $3 \%$ MOLP and 3\% MOLPE were the best treatments and had a good appearance, flavor, color, body and texture than other treatments. So made Halloumi cheese by using 0\%MOLP (T1) as control, 3\% MOLPE (T2) and 3\% MOLP (T3).Therefore, the analyzed for physico-chemical, microbiological, and organolepetical properties in fresh Halloumi cheese were determined. This finding is in line with an earlier report by Apilado et al. (2013).Who showed the consumer acceptability of cream cheese with $0.5,1$ and $1.5 \%$ MLP was lower than $0 \%$ MLP. This indicates that malunggay leaf powder cannot be added to cream cheese from buffalo's milk at the levels used in the study. Inclusion rate for malunggay powder lower than $0.5 \%$ should be considered in the production of cream cheese. 
Table 1. Organoleptic Properties of Moringa Oleifera Leaves Powder (MOLP) or Moringa oleifera Leaves Powder Extract (MOLPE) in Production of Halloumi cheese.

\begin{tabular}{|l|l|l|l|l|l|l|}
\hline MOLP \% & $\begin{array}{l}\text { Apprance } \\
(20 \%)\end{array}$ & $\begin{array}{l}\text { Flavor } \\
(40 \%)\end{array}$ & $\begin{array}{l}\text { Body } \\
\text { textuer } \\
(20 \%)\end{array}$ & $\begin{array}{c}\text { Colour } \\
(20 \%)\end{array}$ & $\begin{array}{l}\text { Total } \\
(100)\end{array}$ & criticisms \\
\hline Control & 19.51 & 37.67 & 18.15 & 18.12 & 93.45 & $\begin{array}{c}\text { Yellowish colour and } \\
\text { semi hard curd }\end{array}$ \\
\hline $1 \%$ MOLP in milk & 10.12 & 12.68 & 11.81 & 7.11 & 41.12 & $\begin{array}{c}\text { Green colour and } \\
\text { very soft curd }\end{array}$ \\
\hline $3 \%$ MOLP in curd & 18.16 & 37.12 & 17.31 & 17.92 & 90.51 & $\begin{array}{c}\text { Yellowish colour and } \\
\text { semi hard curd }\end{array}$ \\
\hline $6 \%$ MOLP in curd & 13.15 & 22.16 & 15.26 & 10.16 & 60.73 & $\begin{array}{c}\text { Very brawn colour and } \\
\text { softer curd }\end{array}$ \\
\hline $1 \%$ MOLPE in milk & 16 & 32 & 16 & 16 & 80 & $\begin{array}{c}\text { Yellowish colour and } \\
\text { semi hard curd }\end{array}$ \\
\hline $3 \%$ MOLPE in milk & 18.71 & 38.12 & 18.01 & 17.69 & 92.53 & $\begin{array}{c}\text { Yellowish colour and } \\
\text { semi hard curd }\end{array}$ \\
\hline $6 \%$ MOLPE in milk & 12.17 & 32.55 & 11.62 & 7.72 & 64.06 & $\begin{array}{c}\text { brawn colour and semi } \\
\text { hard curd(very soft) }\end{array}$ \\
\hline
\end{tabular}

Cheese yield: The average cheese yield \% of the all treatments of Halloumi cheese are illustrated in Table (2) produced from T1, T2, and T3 after one day (fresh) was $9.35,12.5$, and 8.75 , respectively. The highest value of cheese yield from $T 2, T 1$, and T3.The results can be attributed to differences in amount of whey yield, evaporative loss and curd yield for making Halloumi cheese Table (2).On the other hand, the treatment MOLPE (T2) had a higher curd yield (kg), Halloumi cheese yield $(\mathrm{kg})$ and yield \% due to the addition of MOLPE. However, the milk required / $\mathrm{kg}$ Halloumi cheese was less than other treatments and also, treatment (T2) the best treatments. Treatment T3 was the highest of whey yield $(\mathrm{kg})$ and milk required / $\mathrm{kg}$ Halloumi cheese but it was the lowest of yield \% due to addition of MOLP in curd, the moringa powder was increased the loss of whey from curd. 
Table 2. Amount of milk, curd, and yield $(\mathrm{kg})$ of the Halloumi cheese made from different treatments.

\begin{tabular}{|c|c|c|c|}
\hline \multirow{2}{*}{ Component } & \multicolumn{3}{|c|}{ *Treatments } \\
\cline { 2 - 4 } & T1 & T2 & T3 \\
\hline Milk yield used $(\mathrm{kg})$ & 40 & 40 & 40 \\
\hline Curd yield $(\mathrm{kg})$ & $4.40 \pm 0.02 \mathrm{~b}$ & $5.5 \pm 0.01 \mathrm{a}$ & $4.0 \pm 0.03 \mathrm{c}$ \\
\hline Whey yield $(\mathrm{kg})$ & $34.93 \pm 0.01 \mathrm{~b}$ & $34.0 \pm 0.04 \mathrm{~b}$ & $35.5 \pm 0.05 \mathrm{a}$ \\
\hline Evaporative loss $(\mathrm{kg})$ & $0.66 \pm 0.02 \mathrm{a}$ & $0.50 \pm 0.04 \mathrm{~b}$ & $0.50 \pm 0.02 \mathrm{~b}$ \\
\hline Halloumi cheese yield (kg) & $3.74 \pm 0.04 \mathrm{~b}$ & $5.0 \pm 0.03 \mathrm{a}$ & $3.50 \pm 0.05 \mathrm{c}$ \\
\hline Milk required / kg Halloumi & $10.70 \pm 0.07 \mathrm{~b}$ & $8.0 \pm 0.05 \mathrm{c}$ & $11.43 \pm 0.03 \mathrm{a}$ \\
\hline Yield\% & $9.35 \pm 0.03 \mathrm{~b}$ & $12.5 \pm 0.04 \mathrm{a}$ & $8.75 \pm 0.06 \mathrm{c}$ \\
\hline
\end{tabular}

* Data are presented as means \pm SD $(n=3)$ T1: control without moringa. T2: added $3 \%$ moringa leaves extract (MOLPE) in milk. T3: added $3 \%$ moringa leaves powder (MOLP) in curd. abcd: Means with different letter among treatments in the same raw are significantly different.

Physico-chemical properties of cheese:The results of the chemical composition of all the experimental Halloumi cheese in fresh are shown in Table (3). Cheese from T2 had a lower significant differences $(P<0.05)$ in moisture content than treatments 1 and 3, although, T3 was significantly lower $(P<0.05)$ as compared to $T 1$, these results can be attributed to differences in chemical composition of the milk by using MOLPE or MOLP for making Halloumi cheese Table (3) all treatments cheese showed significant differences $(P \leq 0.05)$ in the TS, a highest was in treatment T2 flowed by T3 and T1 and also WSN content and Fat/DM. On the other hand, protein content 21.33, 23.28 and 22.87 in the same order. Similar results were obtained by Anifantakis and Kaminarides (1982). However, the Fat/DM it was $44.59,43.47$ and $43.77 \%$ for treatments $T 1, T 2$ and $T 3$ respectively. The effect of F/DM on meltability, which was important factor for Halloumi. According use to findings of Panayiotatheophil and Andrewwilbey (2007).

Treatment (T2) had a higher TS, fat, protein, WSN, salt, salt in moisture and ash, than other treatments. These results are mainly attributed to the addition of MOLPE. The moisture contents of Halloumi cheese were 43.38, 41.52 and 42.93 for treatments T1, T2and T3 respectively, the moisture contents from all treatments were within the Egyptian Standards for semi-hard cheeses (40-50\%).Also, the obtained results of the produced Halloumi cheese were in agreement with that obtained by Anifantakis and Kaminarides (1982). The average values of salt were among of (1.85 $2.04 \%$ ) the differences in salt content of all treatments were mainly due to the variation in moisture content of Halloumi cheese, whereas the average value of salt was increased in (T2), according to findings of Milci et al. (2005) 
Table 3. Physico-chemical properties of the Halloumi cheese made from different treatments.

\begin{tabular}{|c|c|c|c|}
\hline \multirow{2}{*}{ Chemical properties } & \multicolumn{3}{|c|}{ *Treatment } \\
\cline { 2 - 4 } & T1 & T2 & T3 \\
\hline Total solids (\%) & $56.62 \pm 0.04 \mathrm{c}$ & $58.48 \pm 0.10 \mathrm{a}$ & $57.07 \pm 0.09 \mathrm{~b}$ \\
\hline Moisture \% & $43.38 \pm 0.03 \mathrm{a}$ & $41.52 \pm 0.10 \mathrm{c}$ & $42.93 \pm 0.07 \mathrm{~b}$ \\
\hline Fat \% & $25.16 \pm 0.02 \mathrm{c}$ & $25.28 \pm 0.01 \mathrm{a}$ & $25.23 \pm 0.03 \mathrm{~b}$ \\
\hline Protein \% & $21.33 \pm 0.03 \mathrm{c}$ & $23.28 \pm 0.02 \mathrm{a}$ & $22.87 \pm 0.08 \mathrm{~b}$ \\
\hline WSN \% & $0.12 \pm 0.02 \mathrm{c}$ & $0.24 \pm 0.01 \mathrm{a}$ & $0.21 \pm 0.02 \mathrm{~b}$ \\
\hline Salt \% & $1.85 \pm .035 \mathrm{~b}$ & $2.04 \pm 0.04 \mathrm{a}$ & $1.94 \pm 0.037 \mathrm{~b}$ \\
\hline Fat/DM\% & $44.59 \pm 0.08 \mathrm{a}$ & $43.47 \pm 0.03 \mathrm{~b}$ & $43.77 \pm 0.12 \mathrm{~b}$ \\
\hline Salt/moisture\% & $4.49 \pm 0.08 \mathrm{c}$ & $4.93 \pm 0.09 \mathrm{a}$ & $4.65 \pm 0.07 \mathrm{~b}$ \\
\hline Ash\% & $4.54 \pm 0.03 \mathrm{~b}$ & $4.63 \pm 0.02 \mathrm{a}$ & $4.52 \pm 0.01 \mathrm{~b}$ \\
\hline
\end{tabular}

* Data are presented as means \pm SD $(n=3)$ T1: control without moringa. T2: added 3\% moringa leaves extract (MOLPE) in milk. T3: added 3\% moringa leaves powder (MOLP) in curd. abcd: Means with different letter among treatments in the same raw are significantly different.

Data presented in Table (4) showed that the mineral content of moringa fortified Halloumi cheese. Fortification of moringa oleifera in T2 and T3 was significantly increased the Calcium, Iron, Zink, Phosphorus, Potassium, and Magnesium content of the Halloumi cheese.

Table 4. Mineral composition $(\mathrm{mg} / 100 \mathrm{~g})$ of the Halloumi cheese made from different treatments.

\begin{tabular}{|c|c|c|c|}
\hline \multirow{2}{*}{ Mineral component } & \multicolumn{3}{|c|}{ *Treatment } \\
\cline { 2 - 4 } & $\mathrm{T} 1$ & $\mathrm{~T} 2$ & $\mathrm{~T}$ \\
\hline Calcium $(\mathrm{mg} / 100 \mathrm{~g})$ & $522.67 \pm 3.01 \mathrm{c}$ & $567.67 \pm 2.51 \mathrm{a}$ & $557.33 \pm 3.06 \mathrm{~b}$ \\
\hline Iron $(\mathrm{mg} / 100 \mathrm{~g})$ & $0.85 \pm 0.02 \mathrm{c}$ & $9.02 \pm 0.03 \mathrm{a}$ & $6.85 \pm 0.26 \mathrm{~b}$ \\
\hline Zinc $(\mathrm{mg} / 100 \mathrm{~g})$ & $1.75 \pm 0.03 \mathrm{c}$ & $4.35 \pm 0.05 \mathrm{a}$ & $3.92 \pm 0.03 \mathrm{~b}$ \\
\hline Phosphorus $(\mathrm{mg} / 100 \mathrm{~g})$ & $395.00 \pm 4.58 \mathrm{~b}$ & $489.00 \pm 4.58 \mathrm{a}$ & $470.33 \pm 1.53 \mathrm{a}$ \\
\hline Potassium $(\mathrm{mg} / 100 \mathrm{~g})$ & $91.33 \pm 1.53 \mathrm{c}$ & $114.33 \pm 2.08 \mathrm{a}$ & $96.33 \pm 1.53 \mathrm{~b}$ \\
\hline Magnesium $(\mathrm{mg} / 100 \mathrm{~g})$ & $27.60 \pm 0.26 \mathrm{c}$ & $40.47 \pm 0.15 \mathrm{a}$ & $39.37 \pm 0.29 \mathrm{~b}$ \\
\hline
\end{tabular}

* Data are presented as means \pm SD $(n=3)$ T1: control without moringa. T2: added $3 \%$ moringa leaves extract (MOLPE) in milk. T3: added 3\% moringa leaves powder (MOLP) in curd. abcd: Means with different letter among treatments in the same raw are significantly different.

This increase in the mineral content in cheese by moringa was due to the presence of higher concentration of these constituents in the dried leaves moringa oleifera. Iron content was important mineral in moringa. Moringa oleifera is the best plant source to confer higher quality protein, appreciable amounts of Calcium, Iron, and Carotenoidsm Fahey, (2005). 
The values of $567.67 \mathrm{mg} / 100 \mathrm{~g}, 9.02 \mathrm{mg} / 100 \mathrm{~g}, 4.35 \mathrm{mg} / 100 \mathrm{~g}, 489 \mathrm{mg} / 100 \mathrm{~g}$, $114.33 \mathrm{mg} / 100 \mathrm{~g}, 40.47 \mathrm{mg} / 100 \mathrm{~g}$ were obtained on Halloumi cheese T2 for $\mathrm{Ca}$, Fe, $\mathrm{Zn}, \mathrm{P}, \mathrm{K}$ and $\mathrm{Mg}$, respectively and were significantly $(\mathrm{P}<0.05)$ higher than other treatments. The increase in mineral content of the supplemented Halloumi cheese with Moringa was due to the presence of higher concentrations of these constituents in the dried leaves of Moringa oleifera. Iron content of T2 increased from 0.85-9.02 $\mathrm{mg} / 100 \mathrm{~g}$. From $10 \mathrm{mg}$ to $15 \mathrm{mg}$ Iron is required on daily basis to growing children and nursing women. Thus $175 \mathrm{~g}$ from Halloumi cheese (T2) can provide $15.79 \mathrm{mg}$ iron on daily basis as $100 \%$ requirement of nursing women and children's requirement $100 \%$ of iron can be eating $175 \mathrm{gm}$ of the fortified Halloumi cheese.

Table 5. Vitamins enumeration (ug/100g) and Antioxidant (DPPH \%) of the Halloumi cheese made from different treatments.

\begin{tabular}{|c|c|c|c|}
\hline \multirow{2}{*}{ Vitamins } & \multicolumn{3}{|c|}{ *Treatment } \\
\cline { 2 - 4 } & $\mathrm{T} 1$ & $\mathrm{~T} 2$ & $\mathrm{T3}$ \\
\hline Vita A $(\mathrm{ug} / 100 \mathrm{~g})$ & $87.67 \pm 2.5 \mathrm{c}$ & $165.33 \pm 18.77 \mathrm{a}$ & $143.67 \pm 2.08 \mathrm{~b}$ \\
\hline Vita B2 $(\mathrm{ug} / 100 \mathrm{~g})$ & $184.00 \pm 3.6 \mathrm{c}$ & $699.67 \pm 10.0 \mathrm{a}$ & $687.67 \pm 3.21 \mathrm{~b}$ \\
\hline Vita B5( ug/100g) & $294.33 \pm 3.51 \mathrm{c}$ & $986.67 \pm 1.53 \mathrm{a}$ & $890.67 \pm 4.04 \mathrm{~b}$ \\
\hline Vita E( ug/100g) & $286.67 \pm 4.93 \mathrm{c}$ & $657.67 \pm 2.5 \mathrm{a}$ & $513.3 \pm 7.6 \mathrm{~b}$ \\
\hline Antioxidant (DPPH \%) & $6.900 \pm 0.01 \mathrm{c}$ & $7.367 \pm 0.02 \mathrm{a}$ & $7.227 \pm 0.02 \mathrm{~b}$ \\
\hline
\end{tabular}

* Data are presented as means \pm SD $(n=3)$ T1: control without moringa. T2: added 3\% moringa leaves extract (MOLPE) in milk. T3: added 3\% moringa leaves powder (MOLP) in curd. abcd: Means with different letter among treatments in the same raw are significantly different.

Data illustrated in Table (5) showed the vitamins concentration (ug/ $100 \mathrm{~g}$ ) in three treatments. The $T 2$ was significantly $(P<0.05)$ higher than other treatments. The increase in the vitamins content of the supplemented Hallomi cheese with Moringa was due to the presence of higher concentrations of these constituents in the dried leaves of Moringa oleifera .Vitamin A in T2 was increased from control by $98 \%$ approximately, T1 as present. The T2 was higher vitamin content (ug/100g) and antioxidant (DPPH\%) of the Moringa supplemented Hallomi cheese 165.33, 699.67, 986.67, 657.67, and 7.367 for vitamin A, vitamin B2, vitamin B5, vitamin E, and antioxidant $(\mathrm{DPPH} \%)$, respectively and were significantly $(\mathrm{P}<0.05)$ higher than other treatments (T1 and T3). Differences in the concentrations of antioxidant activity determined on DPPH between the supplementation and the control Halloumi cheese were summarized in Table (5). The values of antioxidant were more abundant in supplementation Hallomi cheese by Moringa as compared with those of control. The results were in agreement with Suzana et al., (2017) who reported the chemical 
constituents of Moringa leaves have antihypertensive effects, anticancer, and antibacterial activity.

Rheological properties of the cheese:The results of rheological examination were presented in Table (6). The data showed that the hardness of cheese were described as the force required to penetrate the sample with the molar teeth (from soft to firm).The Hardness, Springiness, Cohesiveness, Gumminess and Chewiness were significantly higher in all treatments $(P<0.05)$. The results observed that generally, in the supplementation Halloumi cheese, Hardness, Springiness, Cohesiveness, Gumminess and Chewiness values increased in supplementation Halloumi cheese T2 comparison with the other treatments $\mathrm{T} 1$ and $\mathrm{T} 3$, may be due mainly to the lower fat/DM and moisture content Table (1), and added Moringa due to the presence of higher concentration of these constituents in the dried leaves moringa oleifera. Iron content was important minerals in moringa. Moringa oleifera as the best plant source to confer higher quality protein, appreciable amounts of Calcium, Iron, and Carotenoidsm, Fahey (2005). The Adhesivenss in control Halloumi cheese without supplementation $\mathrm{T} 1$ was higher than others treatments may be due mainly to increase the moisture and fat/DM in control than others. The sensory properties, the springiness referred to the degree to which the sample returned to the original shape after partial compression between the tongue and hard palat. Bourne (2002), reported that the gumminess is directly proportional to firmness, and therefore, gumminess decrease with reduced firmness.

Table 6. Rheological properties of the Hallomi cheese made from different Treatments.

\begin{tabular}{|l|c|c|c|}
\hline \multirow{2}{*}{\multicolumn{1}{c|}{ Rheological properties }} & \multicolumn{3}{|c|}{ *Treatment } \\
\cline { 2 - 4 } & $\mathrm{T} 1$ & $\mathrm{~T} 2$ & $\mathrm{~T} 3$ \\
\hline Hardness $(\mathrm{kg})$ & $8.46 \pm 0.06 \mathrm{~b}$ & $9.3600 \pm 0.03 \mathrm{a}$ & $5.8433 \pm 0.03 \mathrm{c}$ \\
\hline Springness & $5.45 \pm 0.04 \mathrm{~b}$ & $5.66 \pm 0.03 \mathrm{a}$ & $5.03 \pm 0.02 \mathrm{c}$ \\
\hline Cohesveness $(\mathrm{kg} \times \mathrm{mm})$ & $0.45 \pm 0.01 \mathrm{a}$ & $0.48 \pm 0.03 \mathrm{a}$ & $0.17 \pm 0.01 \mathrm{~b}$ \\
\hline Gumminess $(\mathrm{kg})$ & $30.59 \pm 0.07 \mathrm{a}$ & $30.69 \pm 0.16 \mathrm{a}$ & $5.85 \pm 0.04 \mathrm{~b}$ \\
\hline Chewiness $(\mathrm{kg} \times \mathrm{mm})$ & $53 \pm 0.03 \mathrm{~b}$ & $71 \pm 0.04 \mathrm{a}$ & $30.17 \pm 0.04 \mathrm{c}$ \\
\hline Adhesiveness & $0.53 \pm 0.003 \mathrm{a}$ & $0.36 \pm 0.004 \mathrm{~b}$ & $0.29 \pm 0.003 \mathrm{c}$ \\
\hline
\end{tabular}

* Data are presented as means \pm SD $(n=3)$ T1: control without moringa. T2: added 3\% moringa leaves extract (MOLPE) in milk. T3: added 3\% moringa leaves powder (MOLP) in curd. abcd: Means with different letter among treatments in the same raw are significantly different.

The rheological role of casein in cheese is to provide a continuous elastic framework for individual cheese granules. Cheese made from (T2) was significantly $(P<0.05)$ greater in gumminess and chewiness than the other cheese, the gumminess 
is the product of hardness, cohesiveness and chewiness of cheese made from (T2) was less adhesiveness but more cohesive than others, these results were in agreement with Kaminarides et al., (2000), and Awad (2011) who described the chewiness to be number of chews required to swallow a certain amount of sample. This property expressed mathematically as the product of gumminess the same trend of those property. Include those factors that affect the curd moisture content (as temperature of coagulation and drain whey), cheese composition, $\mathrm{pH}$, casein and serum protein, Ca content ,salt, fat and manufacturing of cheese for its many desirable functional and texture. In addition, increasing the moisture content might result in increase in the level of free moisture in cheese, this increased the hardness.

Table 7. Microbiological enumeration (log cfu/g) of the Halloumi cheese made from different treatments.

\begin{tabular}{|c|c|c|c|}
\hline \multirow{2}{*}{$\begin{array}{c}\text { Microbiological enumeration } \\
\text { (log cfu/g) }\end{array}$} & \multicolumn{3}{|c|}{ *Treatment } \\
\cline { 2 - 4 } & $\mathrm{T} 1$ & $\mathrm{~T} 2$ & $\mathrm{~T} 3$ \\
\hline Total bacterial & $3.73 \pm 0.2 \mathrm{a}$ & $2.03 \pm 0.15 \mathrm{~b}$ & $1.88 \pm 0.015 \mathrm{c}$ \\
\hline Coliform & $\mathrm{ND}$ & $\mathrm{ND}$ & $\mathrm{ND}$ \\
\hline Staph.aureus & $\mathrm{ND}$ & $\mathrm{ND}$ & $\mathrm{ND}$ \\
\hline E.coli & $\mathrm{ND}$ & $\mathrm{ND}$ & $\mathrm{ND}$ \\
\hline molds \& yeasts & $\mathrm{ND}$ & $\mathrm{ND}$ & $\mathrm{ND}$ \\
\hline
\end{tabular}

* Data are presented as means \pm SD $(n=3)$ T1: control without moringa. T2: added 3\% moringa leaves extract (MOLPE) in milk. T3: added 3\% moringa leaves powder (MOLP) in curd. abcd: Means with different letter among treatments in the same raw are significantly different.

Microbiological analysis: The evaluation of total bacteria counts, coliform, staphylococcus bacteria and molds and yeasts counts in fresh Halloumi cheese samples were shown in (Table 7). The differences for the total plate count of bacteria for all samples were significant $(P<0.05)$. Higher values were obtained for cheese control (T1) than other treatments, the total count were 3.37, 2.03, and 1.88 (log cfu / g) for cheese from $T 1, T 2$, and $T 3$, respectively. The reduction of the bacteria population might be occurred due to the high phenolic compound content and other antimicrobial of Moringa .The results were in agreement with Suzana et al., ( 2017) who reported that the constituents of Moringa leaves had antihypertensive effects, anticancer, and antibacterial activity, namely 4 (4'-0-acetyl-a-L-rhamnopyranosyloxy) benzylisothiocyanate, 4-(a- Lrhamnopyranosyloxy) benzylisothiocyanate), niazimicin $A$ and B pterygospermin, benzyl isothiocyanate, and 4-(a-L-rhamnopyranosyloxy), niazimicin A and B pterygospermin, benzyl isothiocyanate, and 4-(a-Lrhamnopyranosyloxy) benzyl glucosinolate. 
The data also indicated that the coliform, staphylococcus and molds and yeasts were not detected in any treatment. These results were in agreement with Milci et al., (2005). They reported that, the total aerobic bacteria counts decreased during the storage. The observed decrease in bacteria growth could be due to the decrease in the amount of remaining sugar (lactose) in cheese and resulting in fewer nutrients for their growth promotion. Nezhad et al., (2013) found significant decrease in all microbiological parameters starting from total viable count, psychrophile and total LAB by increasing the brine salinity during processing until final product. The yeasts isolated from the commercial samples of fresh and mature Halloumi cheeses did not have any adverse effects on the flavour or produce visible defects. A new lactobacillus strain had been isolated from mature Halloumi cheese made in Cyprus, which that the organism uporteal was resistant to high salt concentrations and low pH (Lawson et al., 2001).

Organolepetical properties: The values of flavor, body and texture, appearance and total were evident from the results of sensory evaluation control T1 and the addition of dry leaves extract and powder Moringa oleifera at T2 and T3, that out the treatment T2 did not have any significant effect $(p<0.05)$ on flavor, body and texture, appearance and total scores. On the other hand, results given in Table (8) showed the organolepetical evaluation of Halloumi cheese made in the three treatments. The total scores organoleptical of $T 2$ was significant higher $(P<0.05)$ than other treatments while T1 did not differ significant within T2and T3, these results were in agreement with those found by Anifantakis and Kaminarides (1982).

The flavor score value, body \&texture, appearance and total scores of all treatments Halloumi cheese were non significant from each other. The Halloumi cheese made from T2 recorded the highest of total score (86.33) followed T1 (75.33) and T3 (71.00). While, score texture and appearance in all treated cheese were not significant. The treatments T2 and T3 supplemented with Moringa were similar as control T1 in organolepetical properties. These results were in harmony with Kaminarides et al., (2015) who studied Halloumi cheese curd was cooked at 93-95 ${ }^{\circ} \mathrm{C}$ for $30 \mathrm{~min}$ as it was not only reduced cheese making time higher sensory scores for the end product cheese. Apilado et al. (2013). Explained that the sensory characteristics of pure cream cheese were significantly higher than those with added MLP. The inclusion levels of MLP had significant negative quadratic relationship with the color and general acceptability of the cheese. Texture, aroma, flavor and aftertaste had significant negative linear relations with the levels of MLP. Consumer acceptability of cream cheese with $0.5,1$ and $1.5 \%$ MLP was lower than $0 \%$ MLP. 
Table 8. Organoleptic evaluation of the Halloumi cheese made from different treatments.

\begin{tabular}{|c|c|c|c|}
\hline Organoleptic evaluation & \multicolumn{3}{|c|}{ *Treatment } \\
\cline { 2 - 4 } & $\mathrm{T} 1$ & $\mathrm{~T} 2$ & $\mathrm{~T} 3$ \\
\hline Flavor (50) & $36.67 \pm 7.6 \mathrm{a}$ & $43.33 \pm 2.8 \mathrm{a}$ & $35.33 \pm 5.0 \mathrm{a}$ \\
\hline Body \& texture (40) & $31.00 \pm 1.7 \mathrm{a}$ & $34.33 \pm 4.0 \mathrm{a}$ & $28.67 \pm 7.7 \mathrm{a}$ \\
\hline Appearance (10) & $7.67 \pm 2.5 \mathrm{a}$ & $8.67 \pm 1.1 \mathrm{a}$ & $7.0 \pm 0.00 \mathrm{a}$ \\
\hline Total (100) & $75.33 \pm 6.8 \mathrm{a}$ & $86.33 \pm 4.1 \mathrm{a}$ & $71.00 \pm 12.7 \mathrm{a}$ \\
\hline
\end{tabular}

* Data are presented as means \pm SD $(n=3)$ T1: control without moringa. T2: added 3\% moringa leaves extract (MOLPE) in milk. T3: added $3 \%$ moringa leaves powder (MOLP) in curd. abcd: Means with different letter among treatments in the same raw are significantly different.

\section{CONCLUSION}

The results of the present study for manufactured Halloumi cheese from fortification of milk by added moringa showed that Halloumi cheese from (T2) was higher in fat, NPN, salt, TS, and salt in moisture, and less hard but more cohesive than others. Fortification with dry leaves powder and extract of Moringa oleifera can be resolve the problem of iron deficiency in women aged 15-50 and children in primary school of the world's population suffer from anemia. It is recommended to produce Halloumi cheese in Egypt from fortification of cow milk by added moringa and thus eating $175 \mathrm{gm}$ fortified Halloumi cheese T2 can provide $15.79 \mathrm{mg}$ iron on daily basis as $100 \%$ requirement of nursing women and children's requirement.

\section{REFERENCES}

1. Anifantakis, E. M. and Kaminarides, S. E. 1982. Contribution to the study of Halloumi cheese made from cow's milk. J. of Agri. Res. 6:119-127.

2. Apilado, O.S., Maria, C.R., O, Ione, G. S., Veneranda, A. M., and Rosalina M. L. 2013. Compostion, sensory quality, and acceptability of cream cheese from pure buffalo's milk added with Malunggay (Moringa oleifera L.) leaf Powder. Philipp J. Vet Anim Sci., 39, 1:91-98.

3. Bourne M. 2002. Food Texture and Viscosity: Concept and Measurement. $2^{\text {nd }}$ ed. San Diego: Academic Press,p 415.

4. A.O.A.C. 1990. Associaction of Official Analytical Chemists. Official Methods of Analysis, 15 Ed .Washington, D.C., pp.803-845.

5. Awad, S. 2011.Texture and Microstructure. In Practical Food and research .(Ed.Rui M,Cru S.),Nova Scinece publishers, Inc. pp.361-391.

6. Duncan, D. B. 1955. Multiple Range and Multiple F-Test. Biometrics, 11, 1-42.

7. Fahey, JW. 2005. Moringa oleifera: A review of the medical and plant for its nutritional therapeutic and prophylactic properties. Part 1. In: trees for Live of Journal Beneficial Trees and Plants. Maryland. 1:1-5. 
8. Houghtby, G,A., Maturin L.J., and Koening E.K. 1992. Microbiologi count methods In: R.T. marshal (Ed). Standard methods for the examination of dairy products (16 Ed. ) American Public Health Association, Washington, D.C, USA. 213-246.

9. Kaminarides, S., Rogoti, E., and Mallatou, H., 2000. Comparison of the characteristics of halloumi cheese made from ovine milk, caprine milk or mixtures of these milks. Int. J. Dairy Technol. 53: 100-105.

10. Kaminarides, S., Ioannis,L., Theophilos, M., and Aikaterini, G. 2015. The effect of cooking time on curd compostion and textural properties of sheep Halloumi cheese. Small. Rumi. Res. 125: 106-114.

11. Kosikowski, F.V. 1982. Cheese and fermented milk. Food $2^{\text {nd }}$ Printing with revision 573.F.V.Kosikowski and associated.P.O.B.139.New York.14817-0139.

12. Lee ,S.C, Kim,J.H., jeong,S.M.,Kim,D.R.,Ha,J.U.,Nam,K.C. 2003. Effect of farinfraraed radiation on the antioxidant activity of rice hulls,J.Agri.and food chemi. 51: 4400- 4403.

13. Lawson, P.A., Papademas. P., Wacher, C., Falsen, E., Robinson, R.K, and Collins, M.D. 2001. Lactobacillus cypricaseisp. nov., isolated from Halloumi cheese. Int. J. of Systematic and Evolutionary Microbiology. 51: 45-59.

14. McLean, E., Cogswell, ME., Egli, I., Wojdyla, D., de Benoist, B., and Mary, B. 2009. Worldwide prevalence of anemia, World Health Organization vitamin and mineral nutrition information system 1993-2005.PublicHealthNutrit;12:44454.https doi.org/10.1017/S1368980008002401; PMid:18498676.

15. Milci, S., Goncu, A., Alpkent, Z, and Yaygın, H. 2005. Chemical, microbiological and sensory characterization of Halloumi cheese produced from ovine, caprine and bovine milk. Int. Dairy J. 15: 625-630.

16. Nelson, J.A., and Trout, G.M. 1981. Judging of Dairy Products , $^{\text {th }}$ Ed. INC Westport, Academic Press, 345-567.

17. Nezhad, M. H. Duc., Han, N. F., and Hosseinian F. 2013. Flaxseed soluble dietary fiber enhances Lactic acid bacterial survival and growth in kefir and possesses high antioxidant capacity.J. Food Res.2:152-163.

18. Panayiotatheophil, O.U., and Andrewwilbey R. 2007. Effects of fat on the properties of Halloumi cheese. Int. J. of Dairy Technol. 60, 1-4

19. SAS. 2004. SAS Institute Inc. SAS User's Guide, Statistics. Cary, NC.

20. Suzana D., Franciscus, D., Retnosari A., Santi, P.S., and Abdul Mun,I. 2017. Effect of moringa oleifera leaves extract against hematology and blood biochemical value of patients with iron deficiency anemia. J. of Young Pharma.9:9-84. 


\section{تأثير إضافة المورنجا أوليفيرا على جودة الجبن الحلوم} نبيل بسيونى الجمل و محمد عرفة محمد موسى وعابد الثو ادفى صالح

$$
\text { قسم كيمياء الألبان - معهد بحوث الإنتاج الحيواني- مركز البحوث الزراعية }
$$

الهدف من هذه الدراسة هو تأثثر إضافة المورنجا على جودة الجبن الحلوم المصنع من اللبن

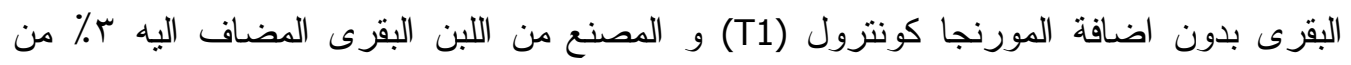

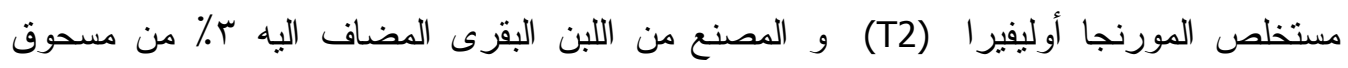
المورنجا أوليفير ا الجافة (T3). كانت المعامله (T2) أعلى فى كمية الخثرة (كجم) ، وكمية جبن حلوم (كجم)، وكذللك نسبه التصافى ٪ بسبب إضافة المورنجا .ومع ذللك، فان كمية اللبن المطلوبه لانتاج

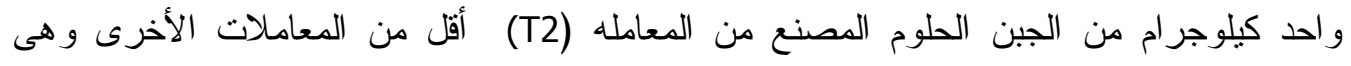

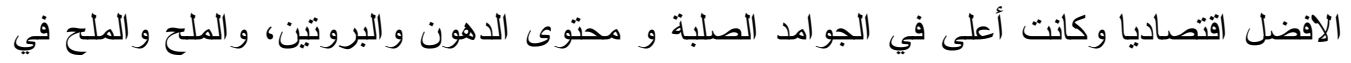

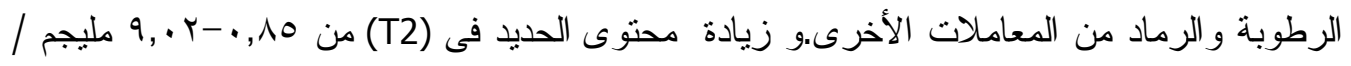

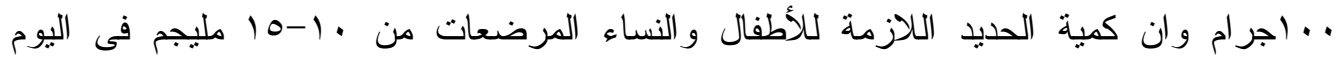

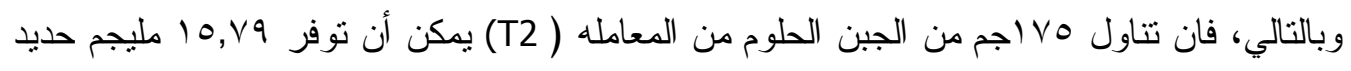

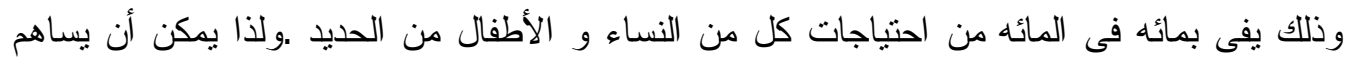
الجبن الحلوم المدعم بمستخلص أوراق المورنجا الجافة فى حل مشكلة نقص الحديد ومكافحة فقر الدم

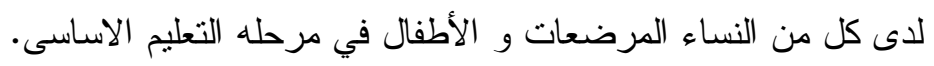

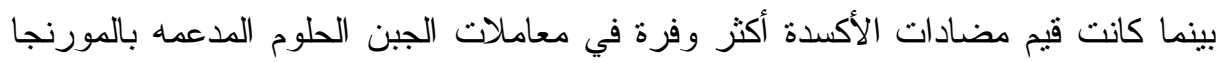
بالمقارنة مع تلك الجبن الغير مدعمه بالمورنجا .الجبن المصنوع من المعامله (T2) كان أكبر معنويا ( chewiness و ون الجبن كل من الأخرى .و عند تقييم عدد البكتريا الكلية وكوليفورم و البكتريا العنقودية و الفطريات و الخمائر في عينات الجبن الحلوم الطازجة فكانت

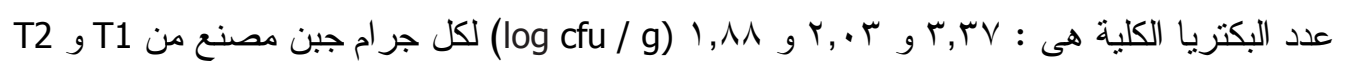
و T3 على التوالي ونقص عدد البكنيريا بسبب ارتفاع محتوى مركب الفينول وغير ها من مضادات الميكروبات فى المورنجا ـ وان التقييم الحسى فى كل المعاملات لم تتأثر بشكل كبير عن بعضيا بـها البعض و لايوجد اختلافات معنوية (0.05> P) بين المعاملات و الكنترول. 
